\title{
The Metaphor of Consumerism
}

\author{
Muhammad Hasyim \\ French Department, Hasanuddin University, Makassar, Indonesia
}

\begin{abstract}
This research uses semiotic of metaphor to unmask the underlying meaning beneath the semiotic of consumerism on television advertisements. This research attempts to explain how advertised products are being used, through the means of semiotic of metaphor by scrutinizing the dynamic relationship between sign and signifier. Semiotic of metaphor makes the products 'alive' within human society hence, this implies that the very existence of human beings is no longer determined by the presence of another human being, instead the very existence is now determined by the presence of certain commercial products in possession. The society, in term of consumerism, views the products as animate or living entities within the sphere of living. Commercial advertisements use metaphorical expressions to relate and exchange in two major concepts: products are humans, and humans are products' users. Thus, nowadays, humans tend to seek their purpose of living and existence through consumerism. The result of this research shows that television commercial advertisements mainly work by means of certain metaphorical symbolism: it shapes society's perspective into believing that the very existence of human beings, the actualization of self, and differentiations among them are achieved by using or purchasing certain advertised products therefore, the products serve as the symbols of those achievements.
\end{abstract}

Index Terms - metaphor, consumerism, semiotic, product, society of consumerism

\section{INTRODUCTION}

Lately, society is stuck in a state of near no-availability of space and time to distant itself from the massive attacks of information, via any advertising tool relating to consumerism. The media as a means of distributing information is occupied by commercial advertisements (television, newspaper, and online media) and thus leads to unstoppable flow of commercial advertisements to the society. This phenomenon is undoubtedly indicating society's transformation into a new age, the age of consumerism. Baudrillard (2011, p. 3), a French social thinker, states that nowadays people are no longer surrounded by their fellow human beings, but objects of commercial consumption. This implies that each individual in a society seeks the very existence, purpose of living, and the meaning of life by purchasing certain products, which is greatly amplified and encouraged by the media that never ceased to flood the society.

Advertisement has occupied society's public spaces; its scope is not merely in term of media in common (television, newspaper, online media), but the extent of places frequently visited by people such as café and mall. Moreover, in selling products to the society, today's advertisements has accomplished techniques that allows the society to believe in it through the use of promises, hopes and solutions, similar to religions, which arouse the collective emotion and mind of the society. Furthermore, the state of believing is made possible through the creation of system of signs by the media (advertisement) as stated by Williamson (1978, p. 12) obviously it (advertising) has a function, which is to sell things to us; it has another function, which I believe in many ways replace that traditionally fulfilled by art or religion.

In this era of globalization of information and technology, media possesses an undoubtedly significant role in shaping the society into one that is driven by consumerism through their floods of advertisements, which consequently leads to the offering of certain lifestyle visually (Chaney, 2011: 11). Moreover, media (advertisement) delivers its message of certain lifestyle in the form of the imagery of subjects as stated by Althusser $(2008$, p. 48) that all ideologies possess the same function to define itself by fabricating concrete individuals as subjects. The process of fabricating individuals into subjects is done through the process of interpretation. This process, has been termed by Althusser (2008, p. 48) as profoundly unconscious process, allows the advertisement media to create certain imagery of their advertised products in which the society unconsciously perceives and treats it as something that is (apparently) deep and thus drive its consciousness into those that believe that using certain products is something that naturally occur or in other words, do not have any influence on outside party.

Baudrillard (1968, p. 252) states that at the moment, we consume product as it is, we simultaneously consume it; this implies that we perceive through advertisements, which is not merely selling the product by exposing its practical usefulness to the society but far beyond. It also sells the product by exposing the social usefulness and creating certain system of ideas within the society; in other words, by constructing certain intended reality of the product it sells. This is in line with Kathy Myers (2012, p. 85) who states that advertisement is not merely creating the brand and informing the practical usefulness of the product being advertised, but the product itself must occur as something human or as something natural.

Considering its significant role in humans' daily live, advertising activity mainly uses the means of language to convey its ideas to the society. The significance of language is highly emphasized by Saussure (1967, p. 33) who states that language is the most important sign among all other sign found in humans daily live. In support of the preceding 
statement, Claire Kramsch (1998, p. 3) also states that language is able to express, create, and symbolize reality: how words are able to convey facts, ideas or events, reflect actions, shape one's perspective of the world and belief, and, eventually, mold reality. Furthermore, language's ability to create certain perception of the world or to create reality leads to the use of language as the main means of advertising activities as stated by Berger and Luckman (1966: 26) that advertisement media in its very essence is a result of reality constructing activities in which language serves as the main instrument. Language is the main element and the main instrument to construct reality. Thus, this leads to a conclusion that advertisement media uses language to construct its favorable.

In all language phenomena, metaphor is used in advertisement media to deliberately fabricate consumerism. The use of metaphor in the advertisement does not directly persuade the society to buy the product being advertised, but provide certain concept that indirectly persuades the society to buy the advertised product. For example, in television commercial advertisement, the advertiser do not use terms that directly and obviously persuade the audience to buy the object being advertised, instead the advertiser provide certain metaphorical expressions, which persuade to buy the object. Thus, this paper attempts to reveal the use of metaphor in the television advertisement of commercial products, which constructs the notion of consumerism.

\section{LITERATURE REVIEW}

\section{Metaphor}

In term of semiotics, metaphor is a way of conceptualizing or relating a sign (topic) to another entity through the use of analogy (differentiations or equations). Metaphor works by employing two signs, i.e., the first serves as the source or domain (topic) and the second serves as the target (vehicle), which give birth to a new meaning (grounds).

A 'topic' in metaphor is the writer/speaker that creates the expression, not the literal meaning of the expression itself while the term 'vehicle' is the metaphorical expression. Then, 'grounds' is the relation between the literal meaning and the metaphorical meaning possessed by the expression. Through the observation of 'grounds', one is able to identify the meaning intended to deliver and what 'prototype' is intended to divert to 'topic' in relation to the literal meaning or the 'vehicle' or the metaphor (Danesi, 2010, p. 59).

The construction of metaphorical meaning is based on the verbal signs that already existed in the society, which took form as social or cultural value, and transformed into a sign that serves as the target in order to construct new meaning. Thus, metaphor is a semiotic process of making new meaning as stated by Lakoff and Johnson (1980, p. 3) that metaphor is pervasive in everyday life, not just in language but also in thought and action. Our ordinary conceptual system, in terms of the way we think and act, is fundamentally metaphorical in nature, thus, given birth to the notion of conceptual metaphor.

In Lakoff and Johnson's conceptual metaphor (1980, p. 3), there are two conceptual domains namely, source domain and target domain. Source domain deals with one's recognition of certain abstract concepts in target domain, which is usually found in humans' everyday lives. Commonly, source domain possess a more concrete concept than target domain since it serves as the base of understanding what is meant in the target domain, which is usually abstract. Organizing the relations among objects, metaphor is able to construct certain understanding towards certain object using other objects as means of understanding. Thus, in other words, source domain serves as the main tool for human to be able to comprehend what is meant by the abstract thing conceived in the target domain.

Further, Lakoff and Johnson (1980, p. 5) also state that the essence of metaphor is understanding and experiencing one kind of thing in terms of another. According to the preceding statement, it is obvious that one is able to comprehend one thing via the understanding of another (preceding) concept already known or comprehended. Moreover, the statement also implies that metaphor is not merely a word or figure of speech in literary works, it goes beyond that. Humans' process of thinking and perception of the world is mostly metaphorical. Furthermore, the two figures above also state that metaphor is generally, yet unconsciously, used in humans' every day activities, not merely in term of language use, but also in term of thinking and doing. Thus, one is able to reveal the other's thought just by observing the way metaphor is used.

Thus, drawing conclusion from the previous explanations, in term of semiotic, metaphor is constructed by two related signs serving as referent. The first sign is coined as 'topic' of the metaphor and the second sign is coined as 'vehicle' of the metaphor or the facility in which metaphorical expression occurred. The relationship between the two signs creates a sign or new meaning (target), which is based on a fusion between two. Consequently, metaphor, a set of complex signs can be concluded in the following figure.

Sign $1+$ Sign 2 = Metaphor

The first and the second signs are constructed by relating the signifier and sign separately. Then, the relation results in the occurrence of new meaning; thus, myth is constructed by metaphorical process.

Consumerism

The term 'consume' can be defined as a process of objectification, or a process of externalization or internalization through certain objects, which serve as the media of such process (Yasraf, 2010, p. 96). In other words, it is a process in which humans' efforts of understanding and conceptualizing the reality and themselves is ruled by the use of certain 
objects as the media. The process constructs certain value through the use of certain objects, gives recognition of the role of certain objects being used as media, and internalizes the value constructed through it.

Consequently, the definition of consumerism above illuminates the motives behind continuous struggle of consumerism. Somehow, the objects of consumptions have transformed into something that is integral of one's true self. In other words, one's true self or the concept of self-completeness is highly depended on the purchased objects, which becomes an integral part of one's self and symbolizes one's self-completeness.

Furthermore, semiotics offers a perspective in defining the term 'consume'. It views 'consume' as a process of exercising or deconstructing signs conceived within the objects. Thus, a simultaneous process of consuming object and internally deconstructing its conceived signs occurred exactly at the same moment.

Objects of consumption, such as television commercial advertisement, tend to put to work and indicate social relations existed within the society. It points out and determines one's true self and certain social symbols. Moreover, objects of consumption are also able to construct social differentiations and manifest on various levels of signs. Thus, the fact has been revealed that consumerism constructed by advertisement media eventually constructs certain meaning of differentiations, which serves as a tool for humans' self-actualization in order to achieve completeness through the consuming activity.

\section{METHOD}

This research used descriptive qualitative method. Bogdan and Biklen (Via Moleong, 2004, p. 248) state that qualitative method is the effort of data analysis which employs participating to the data, organizing the data, classifying the data, synthesizing the data, identifying the pattern of the data, revealing the most important thing of the data, and deciding what to tell to the others regarding the data.

The purposes of descriptive qualitative research were making systematic, factual, and accurate description about the object under analysis and drawing the result of the analysis in a narrative form based on relevant theories. The data of the research were jargon, tagline, and narrative texts of television commercial advertisements.

The instrument of the research used in collecting the data was a video recorder. The form of data of the research was video recording collected from television commercial advertisement. The process of recording was conducted at 19.0021.00 since it was recognized as the time when most people watch television (prime time). During the prime time, the researcher recorded the commercial advertisement and continuously changed the television channel using remote control in order to find another advertisement. Thus, the object of the research was motorcycle advertisements, i.e., Honda Vario, Honda BeAt, Suzuki Nex, and Yamaha Jupiter MX.

\section{RESUlts}

Metaphor works by relating two signs, one as a source or topic and other one as vehicle or facility to construct a new meaning or grounds. Metaphor is a semiotic process to make certain sign (sign meaning). Metaphor, which conceptualizes human as objects of consumption is found in the advertisement of Suzuki Nex, Suzuki Satria, and Honda Vario)

\section{Suzuki Nex with tagline 'Suzuki Nex, You are Nex, yang lain End'}

Suzuki Nex advertisement depicted the story of friendship in a certain group of youngsters. The story begins when a girl who is a member of the group worries because her fellow group members are yet to arrive at the place they agreed to practice dancing. Then, a boy in the group suggests contacting their fellow via text; anyone that gets the text is supposed to forward it to the other. Consequently, they agreed to ride Suzuki Nex to the practice and get in touch at some point while on their way to the place. During the course, Suzuki Nex is displayed as a motorcycle that is agile, nimble and fuel-efficient by showing the fuel indicator with no change before, during, and after the trip. As soon as they arrive at the place, then they start to dance.

Advertisement text:

Narrator: Are you ready for Nex?

Figure 1: Gimana nih kok nggak pada dateng? (Where is everybody?)

Theme song: Dengan kuterasa hampa (I was so hollow)

Figure 2: Gue ada ide (I have an idea)

Narrator: Ini cerita tentang persahabatan (This is a tale of friendship)

Figure 3: Kayaknya mereka butuh bantuan kita deh (I think they need our help)

Narrator: Kesetiakawanan (Solodarity)

Theme song: Nex. Nex. Hanya dirimu selalu, Nex..Nex.. (Nex. Nex. No one but you, Nex, Nex..)

Narrator: Suzuki Nex

Figure 4: You are Nex

Figure 1: Yang lain end (the other, end)

Theme song: Nex, Nex, Nex....

The tagline of Suzuki Nex is You are Nex, yang lain end which consisted of two parts, the first one is 'You are Nex', and the other one 'Yang lain end'. In the metaphorical expression of You are Nex, there are two inter-related referents in 
form of pronouns, 'You' and 'Nex'. The first referent or topic is the word 'You' while the second referent or the vehicle is the word 'Nex', and thus combined and create a metaphorical meaning of You are Nex.

Structure of Metaphor of Suzuki Nex

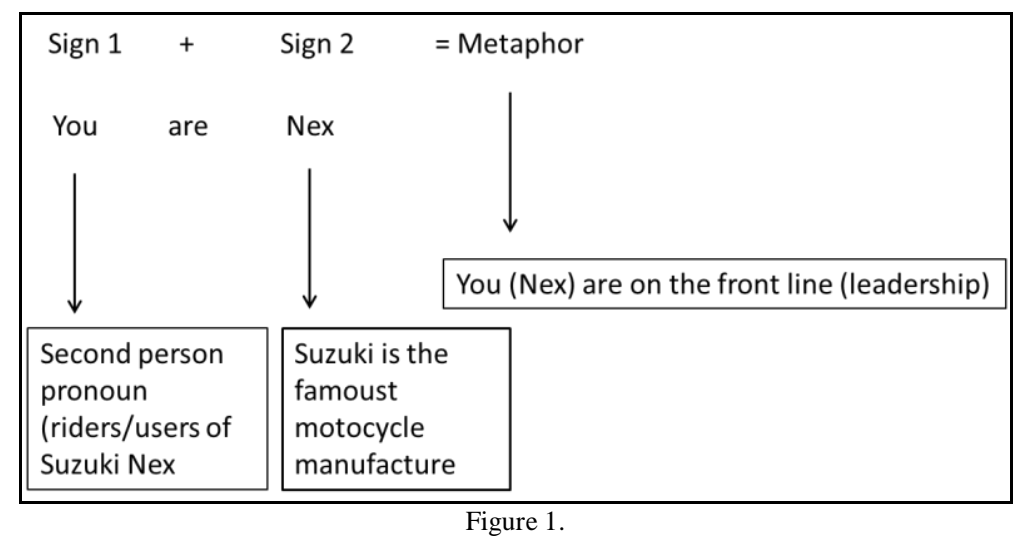

The verbal sign of 'You' is a pronoun and greeting the audience. The verbal sign of 'Nex' is derived from the word 'next' which means coming immediately afterwards and the brand of the motorcycle being advertised. In term of metaphor, the word 'you' refers to those being greeted and persuaded to ride Suzuki Nex, or the audience who watch the advertisement, while the word 'Nex' refers to the brand of the motorcycle which possesses the symbolic meaning of self-identity and distinctive characteristics of Nex motorcycle, speed and leadership. The relation between these two signs creates new meaning that 'you' are the first to ride Nex, 'you' are the leader, the foremost among the other motorcycle manufactures. The concept of leadership defines the identity and distinctive characteristic of Suzuki Nex.

Moreover, the tagline of Suzuki Nex also points out the polarization of front versus back. The phrase You are Nex is the front concept (being the foremost) and the phrase yang lain end is the back concept (being the least). This polarization or concept of metaphorical orientation of front versus back also has a broad meaning of 'becoming leader': Suzuki Nex is the leader and most prominent automatic motorcycle among all.

Honda Vario with the tagline 'I am Vario'

The advertisement of Honda Vario motorcycle introduces the newest product in the era of automatic motorcycle namely Vario 125. The advertisement, which features the well-known singer Agnes Monica, illustrates Honda Vario 125 as the newest technologically and the most prominent automatic motorcycle through its advantages, best design, best performance and the most fuel-efficient motorcycle. It also asserts that Honda Vario 125 is the future automatic motorcycle through the tagline I am Vario, right for the future.

Advertisement text

Memasuki era baru skuter terbaru terbaik (Entering the new era of automatic motorcycle)

Dengan The All New Vario 125, saatnya kamu rasakan (With The All New Vario 125, it is the time to know)

Desain terbaik, Performa terbaik, dan paling irit (Best design, best performance, and the most fuel-efficient)

I am Vario 125, right the future

Honda One Heart

The advertisement of Honda Vario, I am Vario, also shows the symbolism metaphor of identity and differentiation, which is conceptualized into the concept of leader (the best). The tagline of Honda Vario consists of two signs as the referents, the pronoun 'I' which serves as the manifestation of Agnes Monica's self-actualization towards certain object (Honda Vario motorcycle). The term 'Vario' itself refers to the advertised brand and conceives the best quality of automatic motorcycle as represented by the expression, "Memasuki era baru skuter terbaru terbaik. Dengan The All New Honda Vario 125, saatnya kamu rasakan desain terbaik, performa terbaik, dan paling irit." The first sign or the topic is the personal pronoun of "I" while the second sign or the vehicle is the term 'Vario'. The relation between two inter-related signs constructs a new meaning that, since Vario is the best automatic motorcycle and the personal pronoun ' $\mathrm{I}$ ' is regarded as the self-actualization of modern humans, only the best of human beings ride Honda Vario 125 . 


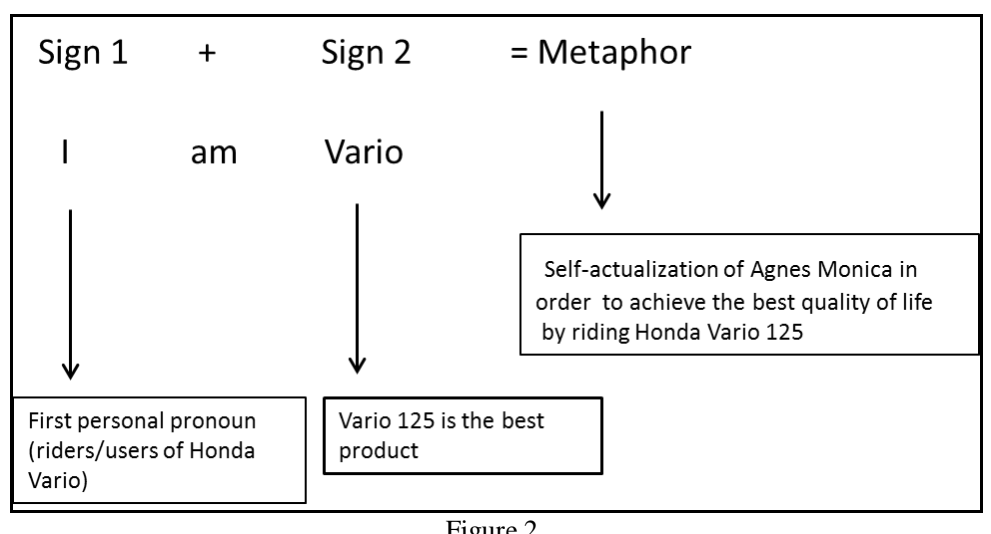

The taglines applied by Suzuki Nex and Honda Vario are both general metaphorical concepts, patterned by the notion of 'humans are objects of consumptions (objects)'. There is also another metaphorical concept, which is regarded as more common, the notion of 'humans are animals' frequently used as means to explain certain concepts of humans in term of animals. Then, it shares the same concept as the metaphorical taglines to describe humans in term of commercial objects. Yet, it does not means that humans are literally objects or animals, it implies that the commercial objects has been given the qualities of hopes, wants, and tastes commonly wanted by humans in their daily lives.

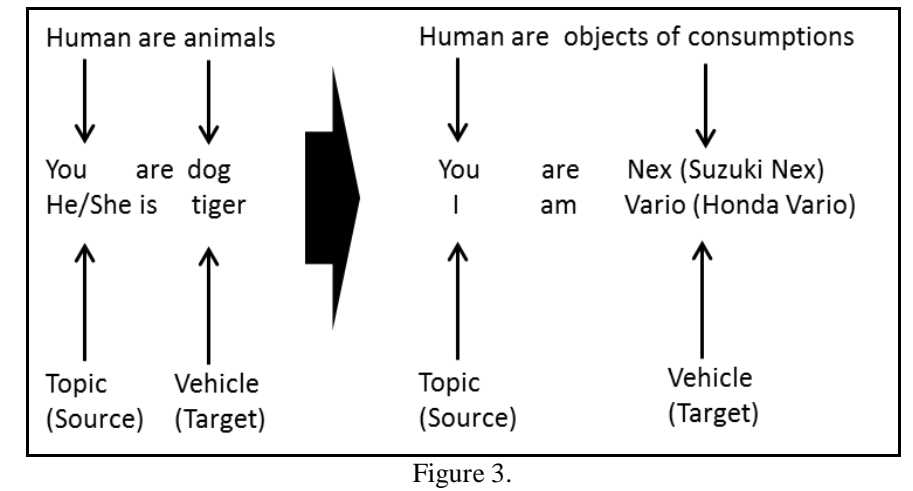

\section{Honda BeAt with the tagline 'Let's get the BeAt'}

The advertisement of Honda BeAt automatic motorcycle begins with a youngster singing with a band. Simultaneously, an automatic motorcycle is introduced in the scene and visually introducing the BeAt. Then, a girl dances and introduces the motorcycle, which is known as Honda BeAt. Consequently, a text appears saying the features of Honda BeAt, "Compact, Cool Fusion, Fun, Stylish", and ended with the tagline of BeAt 'Let's get the BeAt.'

Advertisement text

Let's get the BeAt

Jiwaku adalah musik, (Music is my soul)

Musik warnai hidupku (Music colors my life)

So let's get the Beat

Cintaku adalah musik (Music is my love)

Musik adalah hidupku (Music is my life)

So let's get the Beat

Let's get the Beat

Cintaku adalah musik (Music is my love)

Musik adalah hidupku (Music is my life)

Let's get the Beat

Cintaku adalah musik (Music is my love)

Musik warnai hidupku (Music Colors my life)

Honda Beat

Idola Skuter Terbaru (The new idol of automatic motorcycle)

Let's Get the Beat

Then, the metaphor of the advertisement is found in the verbal sign of 'BeAt'. The verbal sign consists of two referents, source and target. The source domain is 'beat' as it is, and the target domain is 'BeAt' as a brand of motorcycle.

The first referent is derived from the English term of 'beat', which means music (beats of music). In the KBBI (Indonesia dictionary), music is explained as something relaxing, entertaining and joyful. The second referent is the 
term 'BeAt' which an abbreviation of 'Be Automatic' and as the brand of the automatic motorcycle being advertised. Thus, the concept conceived by the term 'beat' is being transferred to the brand of 'BeAt' and, consequently, results in the metaphorical concept of 'Honda BeAt is music' which resembles the traits of music such as relaxing, entertaining and joyful.

\begin{tabular}{llll|}
\hline Sign $1 \rightarrow$ Sign 2 & $\rightarrow$ & Metaphor \\
Beat & BeAt & Honda Beat is music \\
Music & Brand of motorcycle
\end{tabular}

Thus, the tagline of Honda BeAt implies a metaphorical concept (BeAt is music) that explains (or conceptualize) humans using plural personal pronoun; its scope includes the one that spoke and those spoken at (us). Then, the use of pronoun 'us' persuades the audience, or costumer in a more precise term, to ride the Honda BeAt automatic motorcycle. Thus, the structure of metaphor of the advertisement is shown as follows:

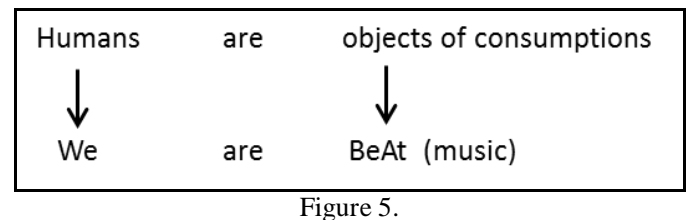

Another metaphor, which applies the same pattern of humans are objects of consumption also found in the advertisement of Suzuki Satria with the tagline, 'Satria, bikin lo beda'.

In the tagline, the metaphorical process is formed with two signs. The first sign or the source domain is the word 'Satria' which means brave men in Indonesian, and the second sign or the target domain is also the term 'Satria' which, in this term, means the brand of the motorcycle being advertised. Then, the relation between these two signs gives birth to a new meaning that Suzuki Satria is a motorcycle that possesses the character of brave men. Thus, the derivation of target domain forms a metaphorical concept that humans are Satria (brave).
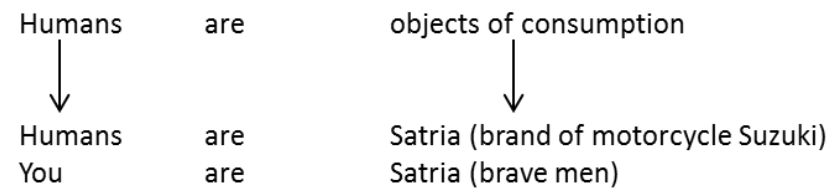

Figure 6.

The metaphorical concept of Suzuki Satria's advertisement is represented in its tagline, 'Satria, bikin lo beda'. The metaphorical concept and the tagline explain how humans (costumers) may acquire the quality of a brave man by riding the Suzuki Satria.

Yamaha Jupiter MX with the tagline 'Jupiter MX, yang lain makin ketinggalan'

The advertisement of Jupiter MX begins with a group of cyborg entering the scene in purpose to find a motorcycle with high-end technology. They eventually find the thing they are looking for, Yamaha Jupiter MX, and do some checks to reveal the features of Yamaha Jupiter MX. The checks they do over Yamaha Jupiter MX alerts them of the advancement of the features of Yamaha Jupiter MX and eventually intend to destroy it because they feel threatened by its advancement. Suddenly, the scene shows Komeng (an Indonesian actor and comedian) rides Yamaha Jupiter MX to get fried rice for his friends. The cyborgs then immediately try to chase Komeng by shooting their weapon at him. Yet, Komeng rides the Yamaha Jupiter MX swiftly and results in the cyborgs' incapability to chase him. Then, Komeng manages to buy the rice and brings it to his friends. The advertisement is then concluded with Komeng introducing the Yamaha Jupiter MX and the jargon of Yamaha, 'Semakin di depan'.

Advertisement text

Cyborg 1: Cari Teknologi canggih itu! (Find the technology!)

Cyborg 2: Ini Teknologi Yamaha super canggih (This is the super high-end Yamaha's technology)

Cyborg 1 : Bahaya menghantam kita. Hancurkan! (Destroy it!)

Komeng : Ada barongsai (What, there are barongsai)

Cyborg 1: Bodoh .... Tangkap dia (Fool! Get him!)

Figure 1: Nasi goreng nih (Aaah fried rice)

Figure 2: Lama amat Meng (You took so long, Meng)

Komeng: Ada barongsai ama kembang api. Ayo makan! (Sorry, I met barongsai and fireworks. Let's eat!)

Komeng:Teknologi Yamaha, yang lain semakin jauh ketinggalan. (Yamaha's technology makes the others left behind, over and over) 
The metaphorical concept of leader is also found in the advertisement of Yamaha Jupiter MX which is represented by its tagline, 'Jupiter MX, yang lain makin jauh ketinggalan'.

The metaphorical concept of the advertisement lies in the word 'Jupiter' which refers to an ancient Roman god with the same name, and consequently refers to the brand of the motorcycle. In Roman mythology, Jupiter is the center of the gods or the leader of the gods, which means that Jupiter possesses the quality of leadership within itself. Then, the quality of leadership possessed by Jupiter is assigned to the brand Jupiter MX, which results in the metaphorical concept of Jupiter MX being the leader of motorcycle in its league. The metaphorical concept of leadership represented through Jupiter MX's swift move is unbeatable when compared to other motorcycles. Thus, it implies that the metaphor of the leadership is the unbeatable swift move of Jupiter MX, which also means that it possesses more advance technology, compared to others motorcycles. The structure of metaphor of Jupiter MX advertisement is shown as follows:

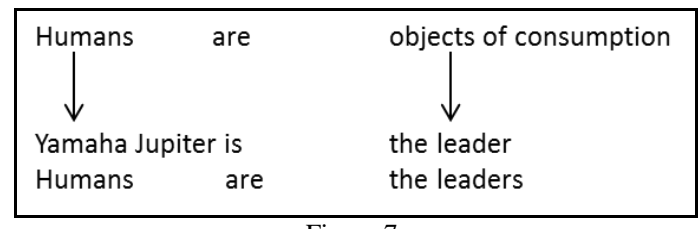

Figure 7.

The conceptual metaphor of Jupiter MX as the leader is transferred to humans using Yahama Jupiter MX. Then, to make a comparison that Yamaha Jupiter MX is better than the others, Yamaha uses the tagline 'Yang lain makin jauh ketinggalan' in which the name of the brand, Yamaha Jupiter MX, already conceives the concept of leadership similar to the Roman god Jupiter.

\section{CONCLUSION}

The metaphorical expressions, found in the advertisement, refer to the social value of leadership. The metaphor of consumerism emphasizing on the existence of individual in the social field is achieved through the use of certain commercial products. Consequently, the metaphor of consumerism implies a system of object that humans find their existence and their very self via the use of commercial objects, or, in other words, humans actualize themselves and find their very self highly dependable on the commercial objects attached to them. Moreover, the metaphor of consumerism also emphasizes on the value of leadership, which ideologically refers to two concepts: consumer as the leader that uses best product and manufacture as the leader on manufactured products.

\section{REFERENCES}

[1] Althusser, Louis. (2008). Tentang Ideologi: Strukturalisme Marxis, Psikoanalisis, Cultural Studies. Yogyakarta: Jalasutra.

[2] Barthes, Roland. (1957). Mythologies. Paris: Editions de Suil.

[3] Barthes, Roland. (1968). Elements of Semiology. New York: Hill and Wang

[4] Baudrillard, Jean P. (1968). Le Système des objets. Paris: Gallimard.

[5] Baudrillard, Jean P. (2004). Masyarakat Konsumsi. (Diterjemahkan oleh Wahyunto). Yogayakarta: Kreasi Wacana

[6] Chaney, David. (2011). Lifestyles, Sebuah Pengantar Konrehensif. (Diterjemahkan oleh Nuraeni). Yogyakarta: Jalasutra.

[7] Danesi, Marcel. (2004). Messages, Signs, and Meanings: A Basic Textbook in Semiotics and Communication Theory. Canada: Canadian Scholars' Press Inc.

[8] Engels Frederick. (2007). Tentang Das Kapital Marx. (Diterjemahkan oleh Oey Hay Djoen) Jakarta : Oey's Renaissance.

[9] Fiske, John. (1987). Television Culture. London: Routledge.

[10] Fiske, John. (1990). Cultural and Communication Studies. London: Routledge.

[11] Hall. Stuart. (1993). Encoding, Decoding dalam 'The Cultural Studies Reader'. Simon During (ed.). New York: Routledge.

[12] Hoed, Benny. (2011). Semiotik dan Dinamika Kehidupan Sosial Budaya. Depok: Komunitas Bambu

[13] Kellner, Douglas. (2010). Budaya Media. Yogyakarta: Jalasutra.

[14] Kramsch, Claire. (2009). Language and Culture. New York: Oxford University Press.

[15] McLuhan, Marshall. (1964). Understanding Media. The Extension of Man. London: Routledge \& Kegan Paul.

[16] Peirce, Charle Sander. (1966). Philosophical Writings of Peirce. (Justus Buchler., Ed.) New York: Dover Publications.

[17] Piliang, Yasraf Amir. (2010). Semiotika dan Hipersemiotika. Kode, Gaya dan Matinya Makna. Bandung: Matahari

[18] Piliang, Yasraf Amir, (2010). Dunia yang Dilipat. Tamasya Melampaui Batas-Batas Kebudayaan. Bandung: Matahari.

[19] Saussure, Ferdinand de. (1967). Cours de Linguistique Générale. Paris: Payot

[20] Sunardi, ST. (2004). Semiotika Negativa. Yogyakarta: Bukubaik.

[21] Williamson, Judith. (1978). Decoding Advertisements. Amerika: Marion Boyars Publishers Inc. 


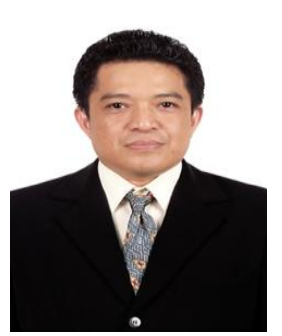

Muhammad Hasyim born on October 28, 1967, has got his master degree of communication science from Hasanuddin University Indonesia in 2006 and $\mathrm{PhD}$ of linguistic program in Hasanuddin University. He focused on the semiotic and media research with semiotic approach and France language teaching in Hasanuddin University. Now, he works as lecturer in the Faculty of letters Hasanuddin University, Indonesia. 